\title{
Growth Performance and Carbon Accumulation of Khaya (Khaya senegalensis) in Sri Lanka
}

\author{
W.M.R.S.K. Warnasooriya ${ }^{*}$ and T. Sivananthawerl ${ }^{1}$ \\ Postgraduate Institute of Agriculture \\ University of Peradeniya \\ Sri Lanka
}

\begin{abstract}
Khaya (Khaya senegalensis) being a new forest plantation species, its growth performance under Sri Lankan conditions has not been evaluated. Further, carbon sequestration by forest plantations, which forms an important option in climate change mitigation, has not gained much attention in Sri Lanka. Hence, the present study aimed at assessing the growth performance and carbon accumulation of Khaya plantations in Sri Lanka. The tree height and tree diameter were measured non-destructively in identified age classes and biomass was estimated with allometric equations. Khaya in Kurunegala division (Intermediate Zone) has achieved $39.98 \mathrm{~cm}$ and $18.31 \mathrm{~m}$ of dbh and height, respectively, by the age of 18-20 years, whereas in Anuradhapura division (Dry Zone) it was $22.21 \mathrm{~cm}$ and $12.41 \mathrm{~m}$, respectively. Significantly higher $d b h$ and tree height $(p<0.05)$ indicates the better site conditions in the Kurunegala division for superior growth of Khaya compared to those in the Anuradhapura division. The dbh and tree height of Khaya showed a strong correlation in both divisions. Significantly higher $(p<0.05)$ biomass of Khaya was recorded in Kurunegala than in Anuradhapura division. The average carbon sequestration of $\underline{K}$. senegalensis was 88.98 and 127.92 t/ha in Anuradhapura and Kurunegala divisions, respectively. Khaya plantations in Anuradhapura division (741.92 ha) and Kurunegala division (475.20 ha) have accumulated 21,785 tand 27,969 t of carbon, respectively. Growth performances evaluated in the present study can guide the future decision making process in establishment of forest plantations in Sri Lanka. Regional baseline carbon estimates of Khaya generated by this study could effectively be utilized for carbon budgeting programmes until validated further by increasing the frequency of measurements of variables and developing allometric relationships specific for $\underline{K}$. senegalensis.
\end{abstract}

Keywords: Age classes, Biomass, Carbon sequestration, Climate change mitigation, Khaya senegalensis

\section{INTRODUCTION}

Khaya (Khaya senegalensis), also known as African mahogany, is a newly introduced forest plantation species to Sri Lanka by the Forest Department of Sri Lanka in 1994. Today it has been identified as one of the promising (Tilakaratna and Weewardane, 1992) and priority species for plantation establishment in the Dry and Intermediate Zones of Sri Lanka (Tilakaratna, 2001) with the main aim of timber production. Besides timber production, they

1 Department of Crop Science, Faculty of Agriculture, University of Peradeniya, Peradeniya, Sri Lanka

* Corresponding author:wmrsanjee@gmail.com 
deliver environmental benefits such as site amelioration, reducing greenhouse effects by sequestering carbon dioxide from atmosphere (Shea et al., 1998) and reducing soil erosion.

Fast growing tree plantations are considered as highly efficient carbon sinks, which have potential to reduce the rate of global warming and the resultant climate change (Brown et al., 1996; Cannell, 1996; Sathaye and Ravindranath, 1998; Malhi and Grace, 2000; White et al., 2000; Schulze et al., 2000; Baker et al., 2004; Grace and Meir, 2009; Lewis et al., 2009). As the forest plantations form an important option for climate change mitigation (IPCC, 2007; Nabuurs et al., 2007), the ability of these plantations to sequester carbon has received renewed interest. In addition to their industrial timber products, the importance of forest plantations has increased substantially during the last two decades in view of the increased awareness on global climate change, and the role of forests in regulating the global carbon cycle (Dixon et al., 1994; Clark et al., 2003; Clark, 2004; Houghton, 2005).

In the Sri Lankan context few studies have focused on the concept of carbon sequestration in forest plantations. The carbon mass as indicated by the standing biomass has not been estimated yet. Estimation of carbon mass will enable economic valuation of Sri Lankan forest plantations to explore possibilities of financial gains through mechanisms such as United Nation's Collaborative Programme on Reducing Emissions from Deforestation and Degradation in Developing countries (UN-REDD) (Gibbs et al., 2007; Ravels, 2008; Schwartzman et at., 2008) and Carbon-trading under Kyoto Protocol's Clean Development Mechanism (CDM) (Fearnside, 1999). Besides, Khaya being a new introduction, evaluation of the growth performance in its predominant and recommended growing localities, i.e. Dry and Intermediate Zones, of Sri Lanka is a timely need. Thus, the present study aimed at assessing the growth performance of Khaya in Sri Lanka, while identifying the environmental benefits through carbon accumulation, to capitalize on its potential in climate change mitigation.

\section{METHODOLOGY}

The study was concentrated on even-aged stands of Khaya plantations distributed in the Anuradhapura and Kurunegala divisions representing the Dry and Intermediate Zones of Sri Lanka, respectively. Potential Khaya plantations of different age classes (1-3, 4-5, 6-7, 8-10, $11-12,13-15,16-17$ and 18-20 years) were identified through a primary land survey with the use of secondary data received from the Forest Department of Sri Lanka. In each division, the age classes were stratified, where sampling was done in different age classes within a division. A minimum of two (02) random sampling plots were chosen for each age class with the size of $10 \mathrm{~m} \times 12.5 \mathrm{~m}(0.0125 \mathrm{ha})$ to gather primary data non-destructively. Data at stand level were collected from 07 locations (beats) in 14 sites (blocks and sub blocks) per division (Figure 1) having a total of 28 sites with 57 sample plots from both divisions. A total of 818 sample trees were subjected to the measurement of total tree height and diameter at breast height $(d b h)$. Age of trees was taken from the records maintained at the Divisional Forest Office of the Forest Department of Sri Lanka. The tree height was measured using a Suunto Clinometer, while a diameter tape was used to measure the diameter at breast height $(d b h)$, i.e. $1.3 \mathrm{~m}$ above the ground level. The GPS coordinates of each location was identified for mapping purpose. 


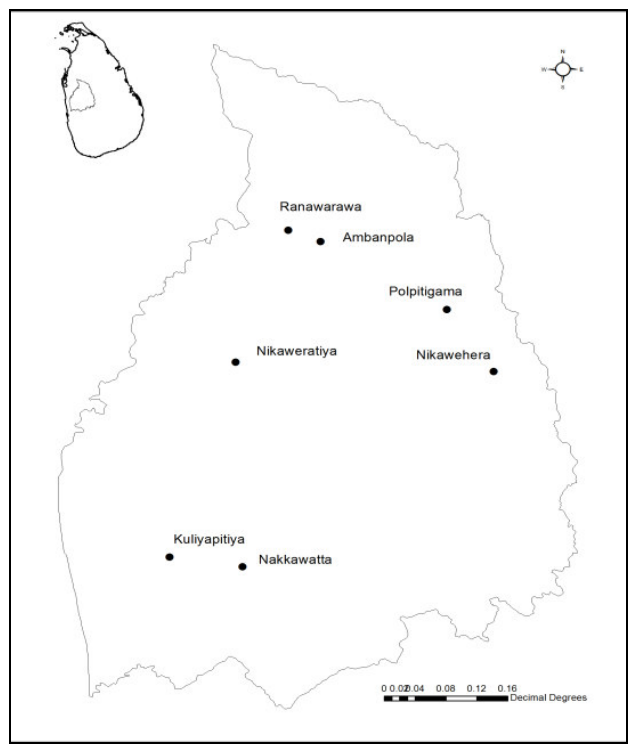

(a)

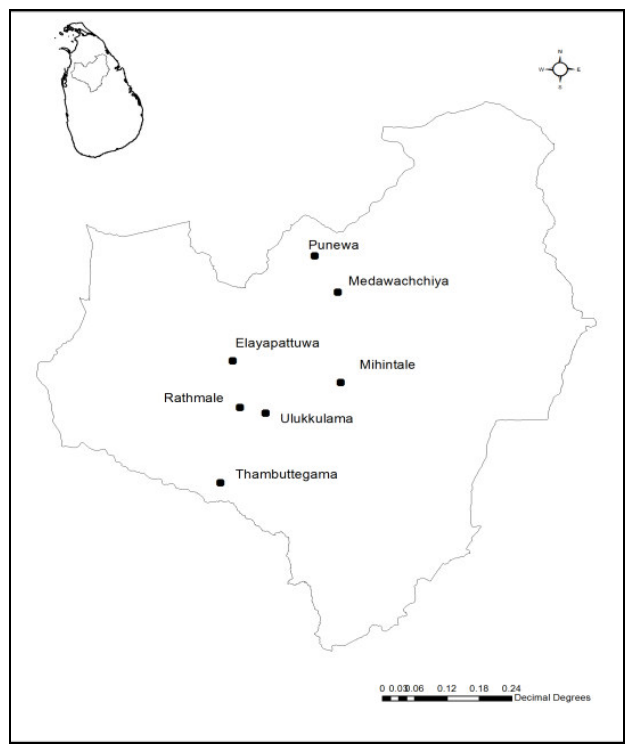

(b)

\section{Fig. 1. Study locations (beats) in (a) Anuradhapura and (b) Kurunegala divisions}

The allometric equations 1 and 2 were used to estimate the biomass and carbon (Pérez and Kanninen, 2003) at stand level;

$$
\begin{aligned}
& \text { LOG Ya }=-0.815+2.382 * \text { LOG }(d b h) \\
& \mathrm{Yb}=\exp (-1.0587+0.8836 * \ln \mathrm{Ya})
\end{aligned}
$$

where; $\mathrm{Ya}=$ above ground biomass of trees $(\mathrm{kg} / \mathrm{tree}), d b h=$ diameter at breast height $(\mathrm{cm})$ and $\mathrm{Yb}=$ below ground biomass of trees $(\mathrm{kg} / \mathrm{tree})$.

The biomass carbon content was estimated by using a standard coefficient of 0.5 (IPCC, 1996). Biomass and carbon values were then scaled to hectare basis, considering thinning age at 7,15 , and 20 years with the stand stock of 1600,800 and 400 trees per ha prior to each thinning, respectively.

Analysis of Variance (ANOVA) was used to test the divisional differences between variables, i.e. $d b h$, tree height, above ground biomass, below ground biomass and total biomass. Mean separation was done using the Least Significant Difference (LSD). Nonlinear regression by dynamic fitting was done to predict the missing data. Analyses were performed with SAS software system (SAS version 9.0).

\section{RESULTS AND DISCUSSION}

Khaya plantations in the Kurunegala division (Intermediate Zone) is distributed in agroecological regions* (AER) $\mathrm{DL}_{1 \mathrm{~b}}, \mathrm{IL}_{3}, \mathrm{IM}_{3 \mathrm{~b}}$, and $\mathrm{IL}_{\mathrm{la}}$, whereas in Anuradhapura division (Dry Zone) they are in agro ecological region $\mathrm{DL}_{1 \mathrm{~b}}$ (Table 1). 
Table 1. Agro-ecological regions (AER) of study locations

\begin{tabular}{|c|c|c|c|c|c|c|}
\hline \multirow{2}{*}{$\begin{array}{l}\text { Age } \\
\text { Class } \\
\text { (years) }\end{array}$} & \multicolumn{3}{|l|}{ Anuradhapura } & \multicolumn{3}{|l|}{ Kurunegala } \\
\hline & Range & Beat & AER & Range & Beat & AER \\
\hline $1-3$ & Anuradhapura & Ulukkulama & $\mathrm{DL}_{1 \mathrm{~b}}$ & $\begin{array}{l}\text { Galgamuwa } \\
\text { Kuliyapitiya }\end{array}$ & $\begin{array}{l}\text { Ambanpola } \\
\text { Kuliyapitiya }\end{array}$ & $\begin{array}{l}\mathrm{DL}_{1 \mathrm{~b}}, \mathrm{IL}_{3} \\
\mathrm{IL}_{1 \mathrm{a}}\end{array}$ \\
\hline $4-5$ & Anuradhapura & Ulukkulama & $\mathrm{DL}_{1 \mathrm{~b}}$ & Galgamuwa & Ambanpola & $\mathrm{DL}_{1 \mathrm{~b}}, \mathrm{IL}_{3}$ \\
\hline $4-5$ & Anuradhapura & Rathmale & $\mathrm{DL}_{1 \mathrm{~b}}$ & Melsiripura & Polpithigama & $\mathrm{DL}_{1 \mathrm{~b}}, \mathrm{IL}_{3}$ \\
\hline $6-7$ & Anuradhapura & Mihintale & $\mathrm{DL}_{1 \mathrm{~b}}$ & Galgamuwa & Ranawarawa & $\mathrm{DL}_{1 \mathrm{~b}}$ \\
\hline $8-10$ & $\begin{array}{l}\text { Anuradhapura } \\
\text { Anuradhapura } \\
\text { Thambuttegama }\end{array}$ & $\begin{array}{l}\text { Mihintale } \\
\text { Rathmale } \\
\text { Thambuttegama }\end{array}$ & $\begin{array}{l}\mathrm{DL}_{1 b} \\
\mathrm{DL}_{1 b} \\
\mathrm{DL}_{1 \mathrm{~b}}\end{array}$ & Galgamuwa & Ambanpola & $\mathrm{DL}_{1 \mathrm{~b}}, \mathrm{IL}_{3}$ \\
\hline $11-12$ & & & & Melsiripura & Nikawehera & $\mathrm{IL}_{3}$ \\
\hline $13-15$ & & & & $\begin{array}{l}\text { Galgamuwa } \\
\text { Kuliyapitiya }\end{array}$ & $\begin{array}{l}\text { Ambanpola } \\
\text { Kuliyapitiya }\end{array}$ & $\begin{array}{l}\mathrm{DL}_{1 \mathrm{~b}}, \mathrm{IL}_{3} \\
\mathrm{IL}_{1 \mathrm{a}}\end{array}$ \\
\hline $16-17$ & Anuradhapura & Elayapaththuwa & $\mathrm{DL}_{1 \mathrm{~b}}$ & Melsiripura & Polpithigama & $\begin{array}{l}\mathrm{DL}_{1 \mathrm{~b}} \\
\mathrm{IL}_{3}, \mathrm{IM}_{3 \mathrm{~b}}\end{array}$ \\
\hline $18-20$ & $\begin{array}{l}\text { Medawachchiya } \\
\text { Medawachchiva }\end{array}$ & $\begin{array}{l}\text { Punewa } \\
\text { Punewa }\end{array}$ & $\mathrm{DL}_{1 b}$ & Mahawa & Nikaweratiya & $\mathrm{DL}_{1 b}, \mathrm{IL}_{3}$ \\
\hline
\end{tabular}

\section{Growth performance of Khaya}

Greater $d b h$ and height of Khaya in Kurunegala division could be attributed to the moisture rich growing conditions in many AERs in the division and other site quality parameters. Khaya being a deciduous tree tends to shed its leaves in the dry spell and retard its growth especially in the Dry Zone, resulting in poor $d b h$ and height gain in the Anuradhapura division (Table 2 and Figure 2). Khaya in Kurunegala division achieved a $d b h$ of $39.98 \mathrm{~cm}$ and a tree height of $18.31 \mathrm{~m}$ by the age of 18-20 years, where as those in the Anuradhapura division recorded a $d b h$ of $22.21 \mathrm{~cm}$ and tree height of $12.41 \mathrm{~m}$ (Table 2) at the same age. Forouhbakhch et al. (2006) reported that the diameter and height are good indicators of site conditions; however, they are also dependent on other factors such as inter-specific competition and stand density. As the stand density of each age class was similar for both divisions, difference in $d b h$ and height can be attributed mainly to site conditions, in which a vast variability did exist under the climate and soil conditions prevailed in the Khaya plantations located at different AERs in Anuradhapura and Kurunegala divisions.

* $\mathbf{D L}_{1 \mathbf{b}}$ : Low country Dry Zone, receives $>900 \mathrm{~mm}$ annual rainfall, experiences bi-modal rainfall pattern and a drought/rain free conditions during Yala season, soil types are reddish brown earth and low humic glay; $\mathbf{I L}_{3}$ : Least potential area belongs low country Intermediate Zone, receives $1200 \mathrm{~mm}$ annual rainfall, soil types are non calcic brown soil (which has low water holding capacity), reddish brown latesolic and low humic gley; $\mathbf{I M}_{\mathbf{3 b}}$ : Low country Intermediate Zone, receives $>1200 \mathrm{~mm}$ annual rainfall mainly from north east monsoon, soil types are reddish brown latasolic and non-calcic brown and reddish brown earth to little extend; $\mathbf{I L}_{\mathbf{1 a}}$ : Low country Intermediate Zone, receives $1400 \mathrm{~mm}$ annual rainfall mainly through south west monsoon, experiences a weak bi-modal rainfall pattern, soil types are red yellow podsolic, reddish brown latesolic, non-calcic brown and regosols (Punyawardana, 2008) 
Table 2. Age vs mean $d b h$ and mean tree height of Khaya in Anuradhapura and Kurunegala divisions

\begin{tabular}{lrrrrrrrr}
\hline \multirow{2}{*}{$\begin{array}{c}\text { Age } \\
\text { Class } \\
\text { (years) }\end{array}$} & \multicolumn{3}{c}{ Mean Height (m) } & \multicolumn{5}{c}{ Mean $\boldsymbol{d} \boldsymbol{b} \boldsymbol{~}(\mathbf{c m})$} \\
\cline { 2 - 9 } & A'pura & StDev & K'gala $^{\prime}$ & StDev & A'pura & StDev & K'gala & StDev \\
\hline $1-3$ & $1.89^{\mathrm{b}}$ & 0.45 & $2.62^{\mathrm{a}}$ & 0.67 & $2.14^{\mathrm{b}}$ & 1.51 & $4.52^{\mathrm{a}}$ & 1.91 \\
$4-5$ & $5.03^{\mathrm{b}}$ & 1.35 & $7.68^{\mathrm{a}}$ & 1.16 & $5.62^{\mathrm{b}}$ & 1.42 & $11.21^{\mathrm{a}}$ & 2.36 \\
$6-7$ & $8.23^{\mathrm{a}}$ & 2.24 & $* 7.77^{\mathrm{a}}$ & - & $12.35^{\mathrm{a}}$ & 4.09 & $* 11.02^{\mathrm{a}}$ & - \\
$8-10$ & $9.99^{\mathrm{a}}$ & 4.81 & $9.23^{\mathrm{a}}$ & 1.40 & $15.15^{\mathrm{b}}$ & 4.53 & $17.34^{\mathrm{a}}$ & 3.21 \\
$11-12$ & $* 11.58^{\mathrm{a}}$ & - & $11.37^{\mathrm{a}}$ & 1.72 & $* 19.33^{\mathrm{b}}$ & - & $17.59^{\mathrm{a}}$ & 3.43 \\
$13-15$ & $* 12.05^{\mathrm{a}}$ & - & $13.00^{\mathrm{a}}$ & 2.67 & $* 20.68^{\mathrm{a}}$ & - & $22.57^{\mathrm{a}}$ & 6.60 \\
$16-17$ & $12.37^{\mathrm{b}}$ & 1.95 & $14.82^{\mathrm{a}}$ & 3.3 & $21.32^{\mathrm{a}}$ & 4.53 & $23.21^{\mathrm{a}}$ & 9.82 \\
$18-20$ & $12.41^{\mathrm{b}}$ & 2.48 & $18.31^{\mathrm{a}}$ & 3.93 & $22.21^{\mathrm{b}}$ & 5.63 & $39.98^{\mathrm{a}}$ & 13.59 \\
\hline
\end{tabular}

Within a column, means followed by the same letter are not significantly different by the Least Significant Different (LSD) at $\mathrm{p}=0.05$

* Values predicted by non-linear regression

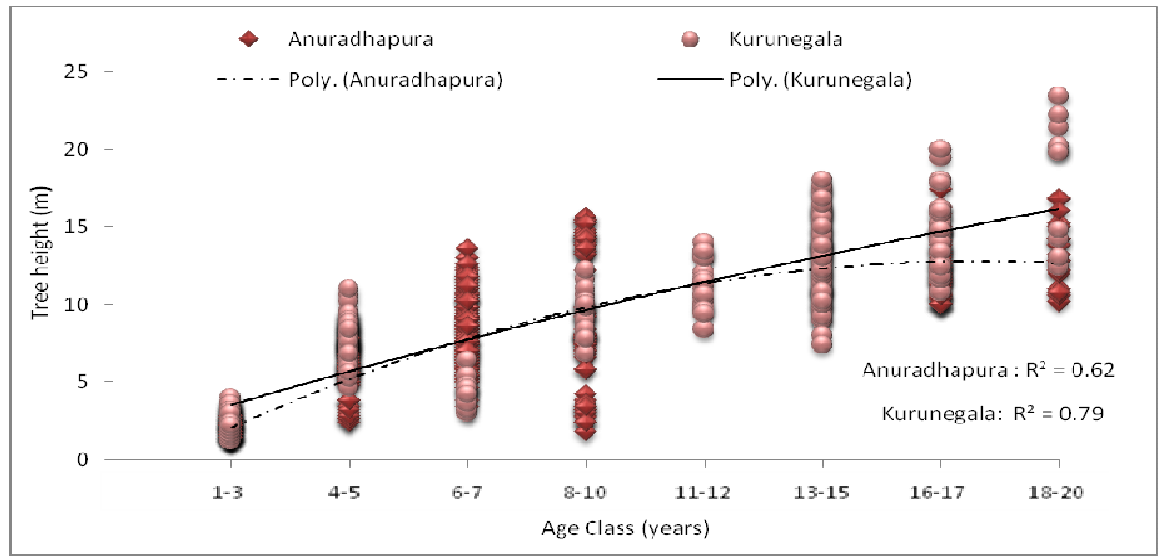

(a)

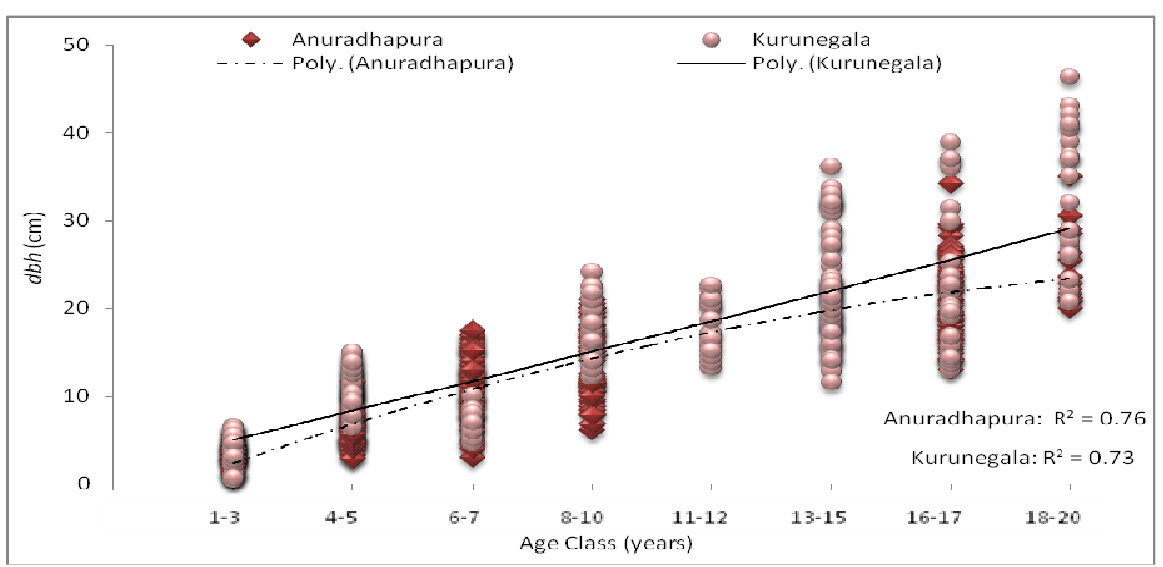

(b)

Fig. 2. (a) Age vs individual tree height and (b) age vs individual dbh of Khaya in Anuradhapura and Kurunegala divisions 
The $d b h$ and tree height of Khaya showed a strong degree of correlation in both Anuradhapura and Kurunegala divisions (Figure 3). As the relationship of $d b h$ and tree height is used to estimate the site quality (Stout and Shamway, 1982), it can be concluded that locations of Khaya plantations in Kurunegala division is superior to that of Anuradhapura. However, a huge site variation did exist in the divisions as they were located in two agro-climatic zones (Intermediate and Dry) while the Khaya plantations were distributed solely in AERs $\mathrm{DL}_{1 \mathrm{~b}}$ in Anuradhapura and $\mathrm{DL}_{1 \mathrm{~b}}, \mathrm{IL}_{3}, \mathrm{IL}_{1 \mathrm{a}}$, and $\mathrm{IM}_{3 \mathrm{~b}}$ in Kurunegala divisions.

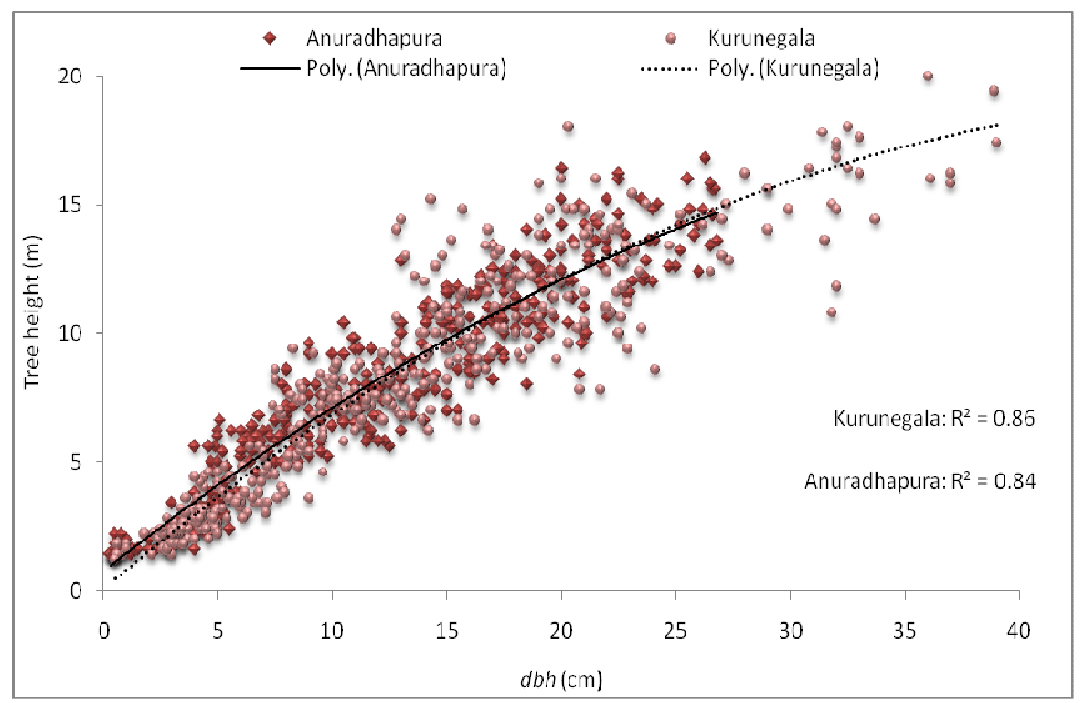

Fig. 3. The relationship between $d b h$ vs tree height of Khaya in Anuradhapura and Kurunegala divisions

\section{Above ground, below ground and total biomass}

A significantly higher $(\mathrm{p}<.05)$ above ground biomass (AGB), below ground biomass (BGB) and total biomass (TB) of Khaya at tree level were recorded in the Kurunegala, attributing to moisture-rich growing conditions (Table 3). In contrast, less annual rainfall and prolonged droughts resulted in a significantly lower $(\mathrm{p}<0.05)$ tree level biomass of Khaya in Anuradhapura. Irregular biomass distribution through age classes was observed from the Kurunegala division (Figure 4). This reflected the climate variation of the different agro ecological regions ( $\mathrm{DL}_{1 \mathrm{~b}}, \mathrm{IL}_{3}, \mathrm{IL}_{1 \mathrm{a}}, \mathrm{IM}_{3 \mathrm{~b}}$ ) within the Kurunegala division, whereas $\mathrm{DL}_{1 \mathrm{~b}}$ was the sole agro-ecological region in the Anuradhapura division (Figure 4) resulting in less variation. Similarly, De Costa and Suranga (2012) reported that carbon stocks of forest plantations vary with their age, while biomass accumulation would be slow in the young plantations until they establish their canopy cover to maximize radiation interception and photosynthesis.

Khaya plantations representing the age classes 6-7 and 11-12 years in the Kurunegala division were located in the agro-ecological regions $\mathrm{DL}_{1 \mathrm{~b}}$, and $\mathrm{IL}_{3}$, which are comparatively drier. The plantations representing the other age classes in the Kurunegala division were distributed in the agro-ecological regions with higher annual rainfall. This explains the lower AGB, BGB and TB per tree recorded from age classes 6-7 and 11-12 years in the Kurunegala 
division (Table 3). Further, Khaya plantations representing the age classes 4-5 and 18-20 years in Kurunegala division were located only in the agro-ecological region $\mathrm{IL}_{1 \mathrm{a}}$, which experiences an annual rainfall $>1400 \mathrm{~mm}$, thus contributing to significantly greater biomass at tree level (Table 3).

Table 3. The above ground biomass (AGB), below ground biomass (BGB) and total biomass (TB) per tree in the Anuradhapura and Kurunegala divisions

\begin{tabular}{lrrrrrr}
\hline $\begin{array}{c}\text { Age } \\
\text { Class } \\
\text { (years) }\end{array}$ & \multicolumn{2}{c}{$\begin{array}{c}\text { AGB } \\
\text { kg/tree }\end{array}$} & \multicolumn{3}{c}{$\begin{array}{c}\text { BGB } \\
\text { kg/tree }\end{array}$} & \multicolumn{3}{c}{$\begin{array}{c}\text { TB } \\
\text { kg/tree }\end{array}$} \\
\hline & A'pura $^{\prime}$ & \multicolumn{1}{c}{ K'gala $^{\prime}$} & A'pura & K'gala $^{\prime}$ & A'pura $^{\prime}$ K'gala \\
\hline $1-3$ & $1.59^{\mathrm{b}}$ & $4.44^{\mathrm{a}}$ & $0.48^{\mathrm{b}}$ & $1.26^{\mathrm{a}}$ & $2.07^{\mathrm{b}}$ & $5.70^{\mathrm{a}}$ \\
$4-5$ & $9.90^{\mathrm{b}}$ & $42.61^{\mathrm{a}}$ & $2.59^{\mathrm{b}}$ & $9.47^{\mathrm{a}}$ & $12.49^{\mathrm{b}}$ & $52.08^{\mathrm{a}}$ \\
$6-7$ & $71.16^{\mathrm{a}}$ & $* 54.70^{\mathrm{a}}$ & $14.64^{\mathrm{a}}$ & $* 11.91^{\mathrm{a}}$ & $85.80^{\mathrm{a}}$ & $* 66.61^{\mathrm{a}}$ \\
$8-10$ & $110.54^{\mathrm{a}}$ & $135.22^{\mathrm{a}}$ & $21.70^{\mathrm{a}}$ & $26.10^{\mathrm{a}}$ & $132.24^{\mathrm{a}}$ & $161.32^{\mathrm{a}}$ \\
$11-12$ & $* 170.18^{\mathrm{a}}$ & $149.89^{\mathrm{a}}$ & $* 32.33^{\mathrm{a}}$ & $28.75^{\mathrm{a}}$ & $* 202.51^{\mathrm{a}}$ & $178.64^{\mathrm{a}}$ \\
$13-15$ & $* 202.56^{\mathrm{a}}$ & $283.29^{\mathrm{a}}$ & $* 37.61^{\mathrm{a}}$ & $49.60^{\mathrm{a}}$ & $* 240.17^{\mathrm{a}}$ & $332.89^{\mathrm{a}}$ \\
$16-17$ & $233.58^{\mathrm{a}}$ & $298.34^{\mathrm{a}}$ & $42.49^{\mathrm{a}}$ & $51.53^{\mathrm{a}}$ & $276.07^{\mathrm{a}}$ & $349.87^{\mathrm{a}}$ \\
$18-20$ & $248.88^{\mathrm{b}}$ & $716.30^{\mathrm{a}}$ & $44.83^{\mathrm{b}}$ & $119.80^{\mathrm{a}}$ & $293.71^{\mathrm{b}}$ & $836.10^{\mathrm{a}}$ \\
\hline
\end{tabular}

Within a column, means followed by the same letter are not significantly different by the Least Significant Difference (LSD) at $\mathrm{p}=0.05$.

* Values predicted by non-linear regression

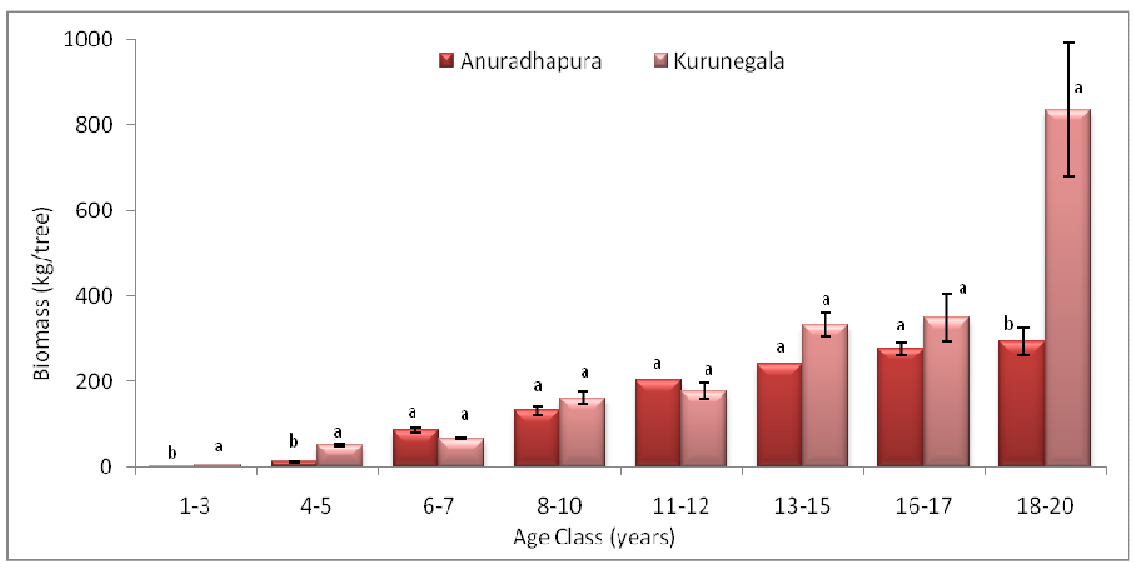

Means followed by the same letter in Anuradhapura and Kurunegala divisions are not significantly different at $\mathrm{P} \leq 0.05$ as determined by Least Significant Difference (LSD). Vertical lines indicate the standard error of the means.

\section{Fig. 4. Biomass distribution in Anuradhapura and Kurunegala divisions}

De Costa and Suranga (2012) reported that carbon estimates are related to the environmental conditions of the respective sites, inferior forest management and/or inferior quality of sites. Further, a combination of higher precipitation that promotes greater photosynthesis and lowered temperature that reduces respiration could also have resulted in high carbon sequestration rates in plants. Khaya plantations in Kurunegala division recording a greater AGB, BGB and TB for many age classes explain this aspect. 
Table 4. Biomass and carbon mass of Khaya at Anuradhapura and Kurunegala divisions

\begin{tabular}{|c|c|c|c|c|c|c|c|c|c|c|}
\hline & \multicolumn{4}{|c|}{ Anuradhapura } & \multicolumn{6}{|c|}{ Kurunegala } \\
\hline $\begin{array}{c}\text { Age } \\
\text { Class } \\
\text { (years) }\end{array}$ & $\begin{array}{r}\text { Biomass/tree } \\
(\mathrm{kg} / \text { tree })\end{array}$ & $\begin{array}{c}\text { Biomass/ha } \\
\text { (t/ha) }\end{array}$ & $\begin{array}{l}\text { Extend } \\
\text { (ha) }\end{array}$ & $\begin{array}{c}\text { Total } \\
\text { Biomass } \\
(\mathrm{t}) \\
\end{array}$ & $\begin{array}{c}\text { Total C } \\
\text { Mass } \\
\text { (t) } \\
\end{array}$ & $\begin{array}{c}\text { Biomass/tree } \\
\text { kg/tree }\end{array}$ & $\begin{array}{c}\text { Biomass/ha } \\
\text { (t/ha) }\end{array}$ & $\begin{array}{l}\text { Extend } \\
\text { (ha) }\end{array}$ & $\begin{array}{c}\text { Total } \\
\text { Biomass } \\
(\mathrm{t}) \\
\end{array}$ & $\begin{array}{c}\text { Total C } \\
\text { Mass } \\
(t) \\
\end{array}$ \\
\hline $1-3$ & $2.07^{b}$ & $3.31^{\mathrm{b}}$ & 325.90 & 1078.73 & 539.36 & $5.70^{\mathrm{a}}$ & $9.12^{\mathrm{a}}$ & 109.00 & 994.08 & 497.04 \\
\hline $4-5$ & $12.49^{\mathrm{b}}$ & $19.98^{b}$ & 90.00 & 1798.20 & 899.10 & $52.08^{\mathrm{a}}$ & $83.33^{\mathrm{a}}$ & 86.20 & $7,182.87$ & $3,591.44$ \\
\hline $6-7$ & $85.80^{\mathrm{a}}$ & $137.38^{\mathrm{a}}$ & 189.41 & $26,021.15$ & $13,010.57$ & $66.61^{\mathrm{a}}$ & $106.58^{\mathrm{a}}$ & 136.40 & $14,536.97$ & $7,268.48$ \\
\hline $8-10$ & $132.24^{\mathrm{a}}$ & $105.79^{\mathrm{a}}$ & 105.81 & $11,193.64$ & $5,596.82$ & $161.32^{\mathrm{a}}$ & $129.06^{\mathrm{a}}$ & 38.10 & $4,917.03$ & $2,458.51$ \\
\hline $11-12$ & $202.51^{\mathrm{a}}$ & $162.01^{\mathrm{a}}$ & 0 & 0 & 0 & $178.64^{\mathrm{a}}$ & $142.91^{\mathrm{a}}$ & 14.00 & $2,000.77$ & $1,000.38$ \\
\hline $13-15$ & $240.17^{\mathrm{a}}$ & $192.14^{\mathrm{a}}$ & 0 & 0 & 0 & $332.89^{\mathrm{a}}$ & $266.31^{\mathrm{a}}$ & 24.50 & $6,524.64$ & $3,262.32$ \\
\hline $16-17$ & $276.07^{\mathrm{a}}$ & $110.43^{\mathrm{a}}$ & 19.80 & $2,186.51$ & $1,093.26$ & $349.87^{\mathrm{a}}$ & $139.95^{\mathrm{a}}$ & 13.50 & $1,889.30$ & 944.65 \\
\hline \multirow[t]{2}{*}{$18-20$} & $293.71^{\mathrm{b}}$ & $117.48^{\mathrm{b}}$ & 11.00 & $1,292.28$ & 646.14 & $836.10^{\mathrm{a}}$ & $334.44^{\mathrm{a}}$ & 53.50 & $17,892.54$ & $8,946.27$ \\
\hline & & & 741.92 & $43,570.51$ & $21,785.25$ & & & 475.20 & $55,938.20$ & $27,969.10$ \\
\hline
\end{tabular}

Within a column, means followed by the same letter are not significantly different by the Least Significant Difference (LSD) at $\mathrm{p}=0.05$ 


\section{Carbon accumulation}

The average carbon sequestration of $K$. senegalensis calculated during the study period were 88.98 and 127.92 t/ha in Anuradhapura and Kurunegala divisions, respectively, while it was 63, 75, 70 and $33 \mathrm{t} / \mathrm{ha}$ for major forest plantation species namely, Tectona grandis, Swietenia macrophylla, Acacia auriculiformis and Eucalyptus camaldulensis, respectively (De Costa and Suranga, 2012). These values are higher than the estimate of benchmark average carbon sequestration of plantation forests in the 'Tropical Dry' climate zone (IPCC 2003), which is $30 \mathrm{t} / \mathrm{ha}$. This confirms that among the major forest plantation species in Sri Lanka, Khaya ranks top in the carbon sequestration capacity due to being a semi-deciduous tree with a dense and expanding canopy with many branches. Further, Khaya recorded a greater carbon sequestration capacity in Kurunegala division compared to that of Anuradhapura.

The total amount of carbon accumulated by the existing Khaya plantations in Anuradhapura division (741.92 ha) and Kurunegala division (475.20 ha) amounted to 21,785 t and 27,969 t, respectively (Table 4). Despite the greater extent of Khaya in the Anuradhapura division, it has accumulated less carbon due to the presence of younger age classes and more stressful conditions imposed by the climate. Further, a greater carbon sequestration capacity of Khaya plantations in the Kurunegala division for each age class has resulted in a greater carbon mass even within a low land extent.

Biomass and carbon values estimated for each age class of Khaya in the present study can be considered as the first overall estimation of biomass and carbon mass carried out in Sri Lanka (Table 4). Despite their approximate nature, these estimates can be used as basic data in carbon budgeting programmes. Further, these estimates can be fine-tuned and made more accurate by increasing the frequency of measurements and by developing specific allometric relationship for $K$. senegalansis.

\section{CONCLUSIONS}

Khaya records significantly higher growth performances and biomass accumulation in the Kurunegala division than in Anuradhapura division, owing to moisture rich growing conditions. Growth performance of Khaya evaluated in the present study can be utilized for decision making on future forest plantation establishment in Sri Lanka and to design a management plan for $K$. senegalensis.

The average carbon sequestration of $K$. senegalensis in Anuradhapura $(88.98 \mathrm{t} / \mathrm{ha})$ and Kurunegala (127.92 t/ha) divisions are well ahead of IPCC's benchmark of plantation forests and major plantation forest species, confirming its potential in climate change mitigation. Biomass and carbon mass generated through present study for each age class of $K$. senegalensis in Anuradhapura and Kurunegala divisions could be considered as regional baselines for forestry carbon projects, until new information is generated. They can be used for carbon estimations in future carbon budgeting programmes with the existing inventory data of the Forest Department of Sri Lanka in a cost effective manner. 


\section{ACKNOWLEDGEMENTS}

The Research Grant (NARP/11/RUSL/AG/03), under the Sri Lanka Council for Agricultural Research Policy (SLCARP) is appreciated for the financial support. Dr. W.C.P. Egodawatta is acknowledged for his contribution in data analysis.

\section{REFERENCES}

Baker, T.R., Phillips, O.L., Malhi, Y., Almeida, S., Arroya, L., Di Fiore, A., Erwin, T., Higuchi, N., Killeen, T.J., Laurance W.F., Lewis, S.L., Monteagudo, Neill, D.A., Vargas, P.N., Pitman, N.C.A., Silva, J.N.M. and Mertinez, R.V. (2004). Increasing biomass in Amazonian forest plots. Philosophical Transactions for the Royal Society London. B359 (1443), 353 - 365.

Brown, S., Sathiya, J., Channell, M. and Kauppi, P. (1996). Mitigation of Carbon emissions to the atmosphere by forest management. Commonwealth Forestry Review. 75(1), $80-91$.

Cannell, M.G.R. (1996). Forests as Carbon Sinks: mitigating the greenhouse effect. Commonwealth Forestry Review. 75(1), 92 - 99.

Clark, D.A. (2004). Sources or sinks? The responses of tropical forests to current and future climate and atmospheric composition. Philosophical Transactions of the Royal Society of London, Series B. 359(1443), 477 - 491.

Clark, D.A., Piper, S.C., Keeling. C.D. and Clark, D.B. (2003). Tropical Rain Forest tree growth and atmospheric carbon dynamics linked to inter annual temperature variations during 1984-2000. Proceedings of the national Academy of Science, USA. 100(10), 5852 5857.

De Costa, W.A.J.M. and Suranga, H.R. (2012). Estimation of Carbon Stock in the Forest Plantations of Sri Lanka. Journal of National Science Foundation. 40(I), 9 - 41.

Dixon, R.K., Brown, S., Houghton, R.A., Solomon, A.M., Trexler, M.C., Wisniewski, J. (1994). Carbon pools and flux of global forest ecosystems. Science. 263, 185 - 190.

Fearnside, P.M. (1999). Forests and global Warming mitigation in Brazil: opportunities in the Brazil forest sector for response to global warming under the "Clean Development Mechanism”. Biomss Bioenergy. 16, 171 - 189.

Forouhbakhch, R., Alvarado-Vazquez, M.A., Hernandez-Pinero, J.L., Rocha-Estrada, A. and Guzman-Lucio, M.A. (2006). Establishment, growth and biomass production of 10 tree woody species introduced for reforestation and ecological restoration in northeastern Mexico. Forest Ecol. Manage., 235, 194 - 201. DOI: 10.1016/j.foreco.2006.08.012.

Gibbs, H.K., Browns, S., Niles, J.O. and Foley, J.A. (2007). Monitoring and estimating tropical forest carbon stocks: making REDD a reality. Environmental Research Letters, 2 (4): 045023:1 - 13. 
Grace, J. and Meir, P. (2009). Tropical rain forests as old growth forests. Old-growth forests: Function, Fate and Value. pp. 391-408. In: Wirth, C., Gleixner, G. and Heimann M. (Ed.) Ecological studies. Volume 207. Springer, Berlin / Heidelberg, Germany.

Houghton, R.A. (2005). Aboveground Forest Biomass and Global carbon Balance. Global Change Biology, 11(6), 945 - 958.

IPCC (1996). Land-Use Change \& Forestry. In: Revised 1996 IPCC Guidelines for National Greenhouse Gas Inventories: Reference Manual, pp. 5.1 - 5. Inter-governmental Panel on Climate Change Geneva, Switzerland.

IPCC (2003). Good Practice Guidelines for Land Use, Land Use Change and Forestry. Intergovernmental Panel on Climate Change Geneva, Switzerland.

IPCC (2007). Summery for Policy Makers. Climate Change 2007: Mitigation. Contribution of Working Group III to the Fourth Assessment Report of the Intergovernmental Panel on Climate Change. (Metz, B., Davidson, O.R., Bosch, P.R., Dave, R. and Meyer L.A. eds.). Cambridge University Press, New York, USA.

Lewis, S.L., Loperz-Gonzalez, G., Sinake, B., Affum-Baffoe, K., Baker, T.R., Ojo, L.O., Reitsma, J.M., White, L., Comiskey, J.A., Djuikouo, M.N., Ewango, C.E.N., Feldpausch, T.R., Hamilton, A.C., Gloor, M., Hart, T., Hladik, A., Lloyd, J., Lovett, J.C., Makan, J.R., Malhi, Y., Mbago, F.M., Ndangalasi, H.J., Peacock, J., Peh, K.S. H., Sheil, D., Sunderland, T., Swaine, M.D., Taplin, J., Taylor, D., Thomson, S.C., Votere and Woll, H. (2009). Increasing carbon storage in intact African tropical forests. Nature. 457(7232), 1003 - 1006.

Malhi, Y. and Grace, J. (2000). Tropical forests and atmospheric carbon dioxide. Trends in Ecology and evolution. 15(8), 332 - 337.

Nabuurs, G.J., Masera, O., Andrasko, K., Benitez-Ponce, P., Boer, R., Dutschke, M., Elsiddig, E., Ford-Roberston, J., Frumhoff, P., Karjalainen, T., Krankina, O., Kurz, W.A., Motsumoto, M., Oyhantcabal, W., Ravindranath, N.H., Sans Sanchez, M.J. and Zhang, X. (2007). Forestry. Climate Change 2007: Mitigation. Contribution of Working Group III to the Fourth Assessment Report of the Intergovernmental Panel on Climate Change (Metz, B., Davidson, O.R., Bosch, P.R., Dave, R. and Meyer L.A. eds.). Cambridge University Press, New York, USA.

Pérez and Kanninen (2003). Chapter 4: Supplementary methods and good practice guidance arising from the Kyoto Protocol (IPCC Good Practice Guidance for LULUCF).

Punyawardana, B.V.R. (2008). Rainfall and Agro Ecological Regions in Sri Lanka. ISBN$978-955-9282-19-8,43-76$.

Ravels, S. (2008). REDD myths: a critical review of proposed mechanisms to reduce emissions from deforestation and degradation in developing countries. Friends of the Earth International. [on line]. [Accessed on 23 July 2009]. Available at http://www.foei.org / en / publications /pdfs / redd- myths / view, 
Sathaye, J.A. and Ravindranath, N.H. (1998). Climate change mitigation in the energy and forestry sectors in developing countries. Annual Review of Energy and Environment. 23, $387-437$.

Schwartzman, S., Nepstad, D. and Moutinho, P. (2008). Getting REDD Right. [on line]. [Accessed on 23 July 2009]. Available at http://www.whrc.org/policy/BaliReports/assets/GettingREDDRight.pdf

Schulze, E.D., Wirth, C. and Heimann, M. (2000). Managing forests after Kyoto. Science. 289(5487), 2058 - 2059.

Shea, S., Butcher, G., Ritson, P., Bartle, J. and Biggs, P. (1998). The potential for tree crops and vegetation rehabilitation to sequester carbon in Western Australia. In: Proceedings of the carbon sequestration conference, Le Meridien at Rialto, Melborn.

Stout, B.B. and Shumway, D.L. (1982). Site Quality Estimation Using Height and Diameter. Forest Science. 28(3), 639-645.

Tilakaratna, D. (2001). Hysipyla shoot borers of Meliaceae in Sri Lanka. Proceeding of an International Workshop, Kandy, Sri Lanka. 20 - 23 August 1996. pp. 3 - 6.

Tilakaratna, D. and Weerwardane, N.D.R. (1992). Evaluation of the initial performance of six timber species in the dry zone of Sri Lanka. Sri Lanka Forester. 20(3/4), 3 - 9.

White, A., Cannell, M.G.R. and Friend, A.D. (2000). $\mathrm{CO}_{2}$ stabilization. Climate change and the terrestrial carbon sink. Global Change Biology. 6(7), 817 - 833. 